\title{
A BAKONYVIDÉK FELSZÍNI KARSZTJA
}

\author{
VERESS MÁRTON - VETÉSI-FOITH SZILÁRD
}

THE SURFACE KARST OF THE BAKONY REGION

\begin{abstract}
In this article, the surface karstification of the Bakony Region is described. For this reason, VES measurements were applied to study the cover and the morphology of the bedrock. A karstmorphological mapping was also performed. With the classification of superficial deposits, karst types were differentiated. A relation was established between the karst types and block types in the mountains. The karstification of the mountains was affected by the block structure of the mountains, the mounds of the uneven bedrock, the presence of superficial deposits and their young (also currently ongoing) denudation. As a result of their individual or simultaneous effect, the karst of the mountains is varied. Soil-covered karst, concealed karst, cryptokarst, mixed autogenic-allogenic karst and allogenic karst occur in the mountains. Soil-covered karst is widespread in the mountains, but the specific features of this type (solution dolines) only occur on the threshold surfaces at the margin of the mountains and on dolomite. The concealed karst was mainly formed on horsts elevated to summit position, but it can also be found on threshold surfaces and on horsts in summit position. Its features are subsidence dolines and depressions of superficial deposit. Burried karst can be created by gravelly cover concerning cryptokarst basalt. The former is characteristic of cryptopeneplains, while the latter is specific of peneplain with basalt caps thus, of Kab Mountain. If the cover is gravel, the water of gravelly terrains seeps into the karst in epigenetic valleys, mainly in their antecedent sections (these are the gorges of the mountains). Phreatic cavity formation takes place at the impermeable intercalations at these sites. The phreatic cavities open up primarily by fluvial erosion. If the cover is basalt, ponors develop at its margin (allogenic karst), while inside, where the basalt thins out, caprock dolines are formed (cryptokarst).
\end{abstract}

Keywords: block type, karst type, subsidence doline, gorge, cave opening

\section{Bevezetés}

\section{A Bakonyvidék általános jellemzése}

E tanulmányban a Bakonyvidék felszíni karsztját mutatjuk be. Karsztját előbb karszttípusokba soroljuk, majd bemutatjuk az egyes karszttípusok morfológiai és genetikai sajátosságait, valamint azok rögtípusonkénti előfordulását.

A Bakonyvidéket $\left(4300 \mathrm{~km}^{2}\right)$ a Bakony hegység $\left(2200 \mathrm{~km}^{2}\right)$ és a körülötte elhelyezkedő, alacsonyabb tájak alkotják. A Bakonyvidék középtáj, amely öt kistájcsoportra (Keszthelyihegység, Balaton-felvidék, Déli-Bakony, Északi-Bakony, Bakonyalja) különül el (1-2. ábra). Karsztjelenségek valamilyen mértékben mindegyik kistájcsoportban jelen vannak (karsztformákban leggazdagabb az Északi-Bakony).

A Bakonyvidék a Dunántúli-középhegység nagytáj (Alpaca nagyszerkezeti egység) részeként, dél-alpi környezetből, északkeleti irányú eltolódással, a miocénre került jelenlegi helyére (STEGENA, L. et al. 1975; CsONTOS, L. - VÖRÖs, A. 2004). Fő felépítő kőzete a triász fődolomit (Fődolomit Formáció), amelyre foltos kiterjedésben, többnyire kis vastagságban (néhányszor 10 m-től néhányszor 100 m-ig) triász dachsteini (Dachsteini Mészkő Formáció), jura, kréta és eocén mészkő települ (3. ábra). 

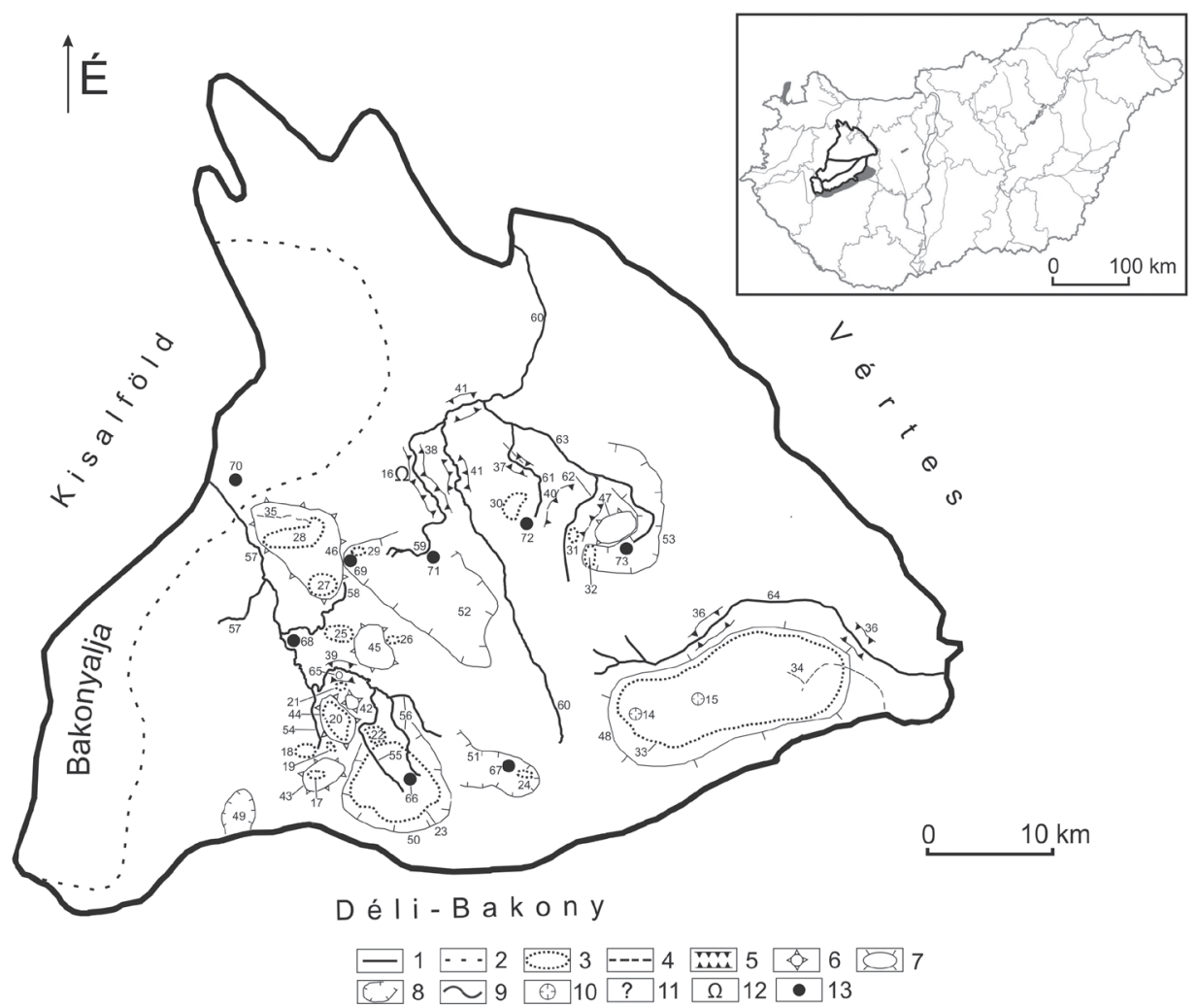

1. ábra A Bakonyvidék É-i részének karsztos képződményei. - 1 - az Északi-Bakony határa; 2 - kistájcsoport határa; 3 - rejtett karszt; 4 - száraz völgy; 5 - szurdok; 6 - rögtetô; 7 -fennsík; 8 - medence; 9 - vízfolyás és völgye; 10 - karsztos depresszió; 11 - felnyílásos barlang; 12 - forrás; 13 - település; 14 - Csengő-akna depressziója (I-51 jelû); 15 - Háromkürtő-akna (I-12 jelû); 16 - Hódos-éri Likas-kő barlang. Rejtett karsztos területek: 17 - a Középsô-Hajagon; 18 - a Felső-Hajagon; 19 - a Fehér-kő-árok mellett; 20 - a Mester-Hajagon; 21 - az Iharos-tető és a Judit-forrás között; 22 - az Égett-hegyen; 23 - a Hárskúti-medencében; 24 - a Lókúti-medencében;

25 - a Som-hegy és a Száraz-Gerence között; 26 - Ósbükkösi töbörcsoport; 27 - Eleven-förtési töbörcsoport;

28 - a Márvány-árok környékén; 29 - Újszépalmapuszta mellett; 30 - a Cuha-patak és Gézaházapuszta között; 31 - a Sűrú-hegyen; 32 - Dudar közelében; 33 - a Tési-fennsíkon; 34 - Tábla-völgy; 35 - Márvány-völgy;

36 - Gaja-szurdok; 37 - Kőmosó-szurdok; 38 - Hódos-éri-szurdok; 39 - Kerteskői-szurdok; 40 - Ördög-völgy szurdokai;

41 - a Cuha szurdokai; 42 - Iharos-tető; 43 - Középső-Hajag; 44 - Mester-Hajag; 45 - Som-hegy; 46 - Kőris-hegy;

47 - Magos-hegy; 48 - Tési-fennsík; 49 - Csehbányai-medence; 50 - Hárskúti-medence; 51 - Lókúti-medence;

52 - Porvai-medence; 53 - Dudari-medence; 54 - Fehér-kő-árok vízfolyása; 55 - Öreg-patak; 56 - Gerence-patak;

57 - Vörös János-patak; 58 - Száraz-Gerence; 59 - Hódos-ér-patak; 60 - Cuha-patak; 61 - Kő-völgy vízfolyása;

62 - Ördög-völgy vízfolyása; 63 - Dudari-patak; 64 - Gaja-patak; 65 - Judit-forrás; 66 - Hárskút; 67 - Lókút; 68 - Bakonybél; 69 - Újszépalmapuszta; 70 - Bakonykoppány; 71 - Porva; 72 - Gézaházapuszta, 73 - Dudar

Figure 1 The karstic features of the northern part of the Bakony Region. - 1 - boundary of the Northern Bakony;

2 - boundary of micro region group; 3 - concealed karst; 4 - dry valley; 5 - gorge; 6 - block roof; 7 - plateau; 8 - basin; 9 - stream and its valley; 10 - karst depression; 11 - cave opening; 12 - spring; 13 - settlement; 14 - depression of

Csengó shaft (marked I-51); 15 - depression of Háromkürtő shaft (marked I-12); 16 - Hódos-éri Likas-kő cave. Concealed karst areas: 17 - on the Középső-Hajag; 18 - on the Felsó-Hajag; 19 - near Fehér-kó Valley; 20 - on the Mester-Hajag;

21 - between the Iharos block and Judit Spring; 22 - on the Égett block; 23 - in the Hárskút Basin; 24 - in the Lókút Basin;

25 - between the Som Mountain and Száraz-Gerence Stream; 26 - doline group at Ósbükkös; 27 - doline group by

Eleven-förtés; 28 - by the Márvány Valley; 29 - near Újszépalmapuszta; 30 - between the Cuha Stream and Gézaházapuszta;

31 - on the Súrú Mountain; 32 - near Dudar; 33 - on the Tési Plateau; 34 - Tábla Valley; 35 - Márvány Valley;

36 - Gaja gorge; 37 - Kőmosó gorge; 38 - gorge of Hódos stream; 39 - Kerteskői gorge; 40 - gorges of Ördög Valley;

41 - Cuha gorges; 42 - Iharos block; 43 - Középső-Hajag block; 44 - Mester-Hajag block; 45 - Som block;

46 - Kőris block; 47 - Magos block; 48 - Tési Plateau; 49 - Csehbánya Basin; 50 - Hárskút Basin; 51 - Lókút Basin;

52 - Porvai Basin; 53 - Dudari Basin; 54 - the stream of Fehér-kő Valley; 55 - Öreg Stream; 56 - Gerence Stream;

57 - Vörös János Stream; 58 - Száraz-Gerence Stream; 59 - Hódos Stream; 60 - Cuha Stream; 61 - the stream of Kő Valley;

62 - the stream of Ördög Valley; 63 - Dudar Stream; 64 - Gaja Stream; 65 - Judit Spring; 66 - Hárskút;

67 - Lókút; 68 - Bakonybél; 69 - Újszépalmapuszta; 70 - Bakonykoppány; 71 - Porva; 72 - Gézaházapuszta; 73 - Dudar 


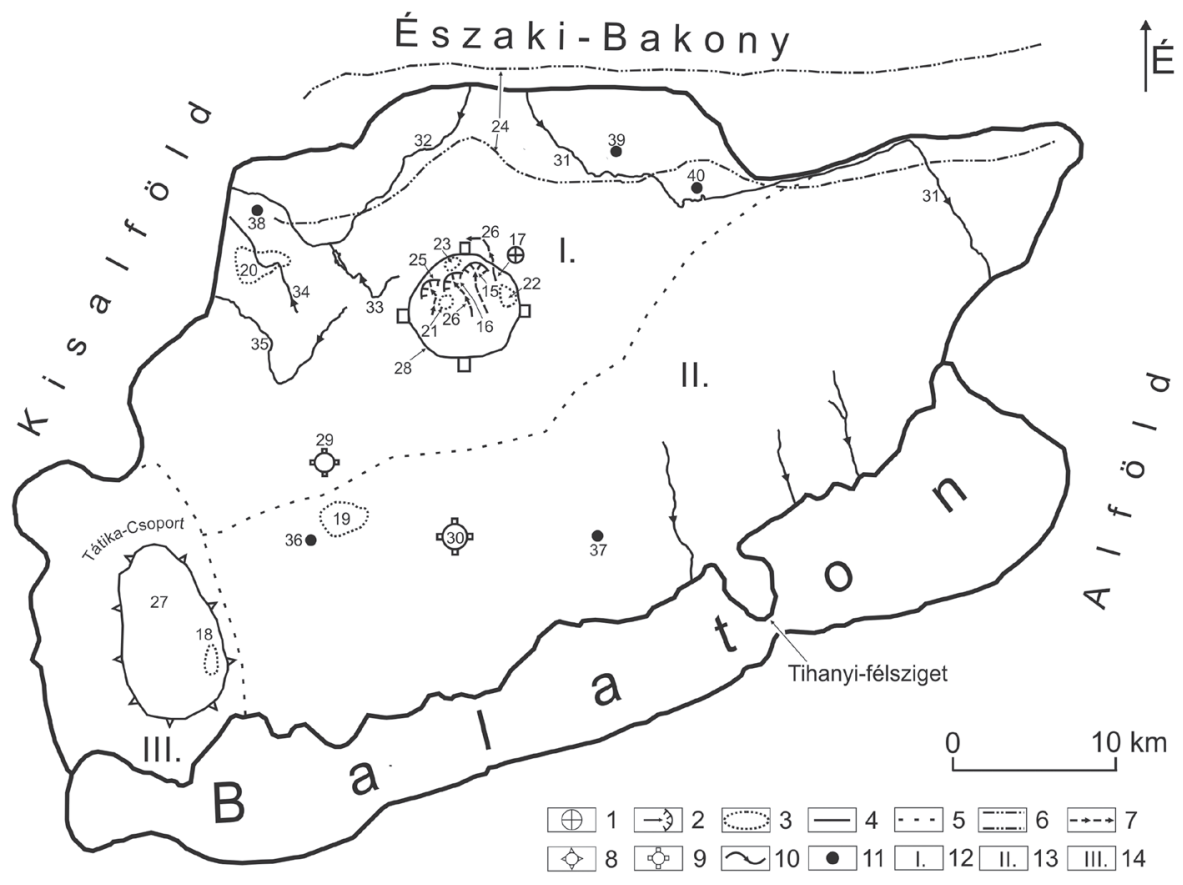

2. ábra A Bakonyvidék D-i részének karsztos képződményei. - 1 - víznyelő; 2 - vakvölgy; 3 - rejtett karszt; 4 - a Bakonyvidék D-i részének határa; 5 - kistájcsoport határa; 6 - tektonikus árok; 7 - szárazvölgy; 8 - fennsík; rögtető; 9 - bazaltsapkás rög; 10 - vízfolyás és völgye; 11 - település; 12 - Déli-Bakony kistájcsoport;

13 - Balaton-felvidék kistájcsoport; 14 - Keszthelyi-hegység kistájcsoport; 15 - Öreg-köves víznyelő;

16 - Macskalik-víznyelő; 17 - Tönkölyös-víznyelő. Rejtett karsztos területek: 18 - a Szabadhegyi-fennsíkon;

19 - Tapolcai-karszt; 20 - Devecser-környékén; 21-23 - a Kab-hegyen; 24 - Veszprém-Devecser-árok;

25 - M-2 jelú depresszió rendszer; 26 - szárazvölgyek a Kab-hegyen; 27 - Keszthelyi-hegység; 28 - Kab-hegy; 29 - Agár-tető; 30 - Fekete-hegy; 31 - Séd-patak; 32 - Torna-patak; 33 - Padragi-víz;

34 - Egres-patak; 35 - Kígyós-patak; 36 - Tapolca; 37 - Dörgicse; 38 - Devecser; 39 - Márkó; 40 - Veszprém

Figure 2 The karstic features of the southern part of the Bakony Region. - 1 - ponor; 2 - blind valley; 3 - concealed karst;

4 - boundary of the southern part of the Bakony Region; 5 - boundary of micro region group; 6 - tectonic graben;

7 - dry valley; 8 - plateau block roof; 9 - block with basalt cap; 10 - stream and its valley; 11 - settlement; 12 - Southern

Bakony micro region group; 13 - Balaton Uplands micro region group; 14 - Keszthelyi Mountains micro region group;

15 - Öreg-köves ponor; 16 - Macskalik ponor; 17 - Tönkölyös ponor. Concealed karst areas: 18 - on the Szabadhegyi Plateau;

19 - Tapolcai Karst; 20 - nearby Devecser; 21-23 - on the Kab Mountain; 24 - Veszprém-Devecser Graben;

25 - depression system marked M-2; 26 - dry valleys on Kab Mountain; 27 - Keszthelyi Mountains; 28 - Kab Mountain; 29 - Agár block; 30 - Fekete Mountain; 31 - Séd Stream; 32 - Torna Stream; 33 - Padragi Stream;

34 - Egres Stream; 35 - Kígyós Stream; 36 - Tapolca; 37 - Dörgicse; 38 - Devecser; 39 - Márkó; 40 - Veszprém

A hegységnek a kréta végi trópusi karsztos tönkfelszíne (SzABó P.Z. 1956, 1968; BuLLA B. 1968) már az eocéntől tektonikusan feldarabolódott (PÉCSI M. 1980), így az oligocén végi, miocén eleji deltakavics (Csatkai Kavics Formáció; KoRPÁs L. 1981) tagolt felszínt borított el. Főleg a hegységperemi részeken alakultak ki fiatalabb, középsőmiocén mészkövek (Lajta Mészkő Formáció, Tinnyei Mészkő Formáció), valamint pliocén édesvízi mészkövek (CsÁszÁr G. et al. 1981). Kis kiterjedésben pannón agyag (JASKó S. 1961) is előfordul, majd széles elterjedésben lösz is képződött.

A Bakonyvidék különböző magasságú rögökre és rögcsoportokra különül. Oszcillációs mozgásaik miatt a rögök különböző fejlődéstörténetúek lehetnek. Ennek figyelembevételével PÉcsi M. (1980, 1991) a hegység sasbérceit (sasbérc-csoportjait) osztályozva elkülönített

- tetőhelyzetú sasbércet (jelenlegi magassága >600m, felszínén triász, jura karbonátos kőzetekkel, esetleg áthalmozott), 
- tetőhelyzetbe kiemelt sasbércet (jelenlegi magassága 400-550 m közötti, kréta és eocén mészkővel, a felszínén széleskörúen elterjedt lösz fedôvel, valamint áthalmozódott üledékkel, esetleg foltokban kavics fedővel); megkülönböztetett továbbá

- kriptotönköt (magassága <300-400 m, felszínét harmadidőszaki üledék és lösz fedi), valamint

- küszöbfelszínt (magassága <300-400 m, felszínét fóleg triász korú karbonátos kőzetek alkotják), amely kavics fedőjét pedimentációval elveszítette, fedője - ha van - áthalmozott (3. ábra).

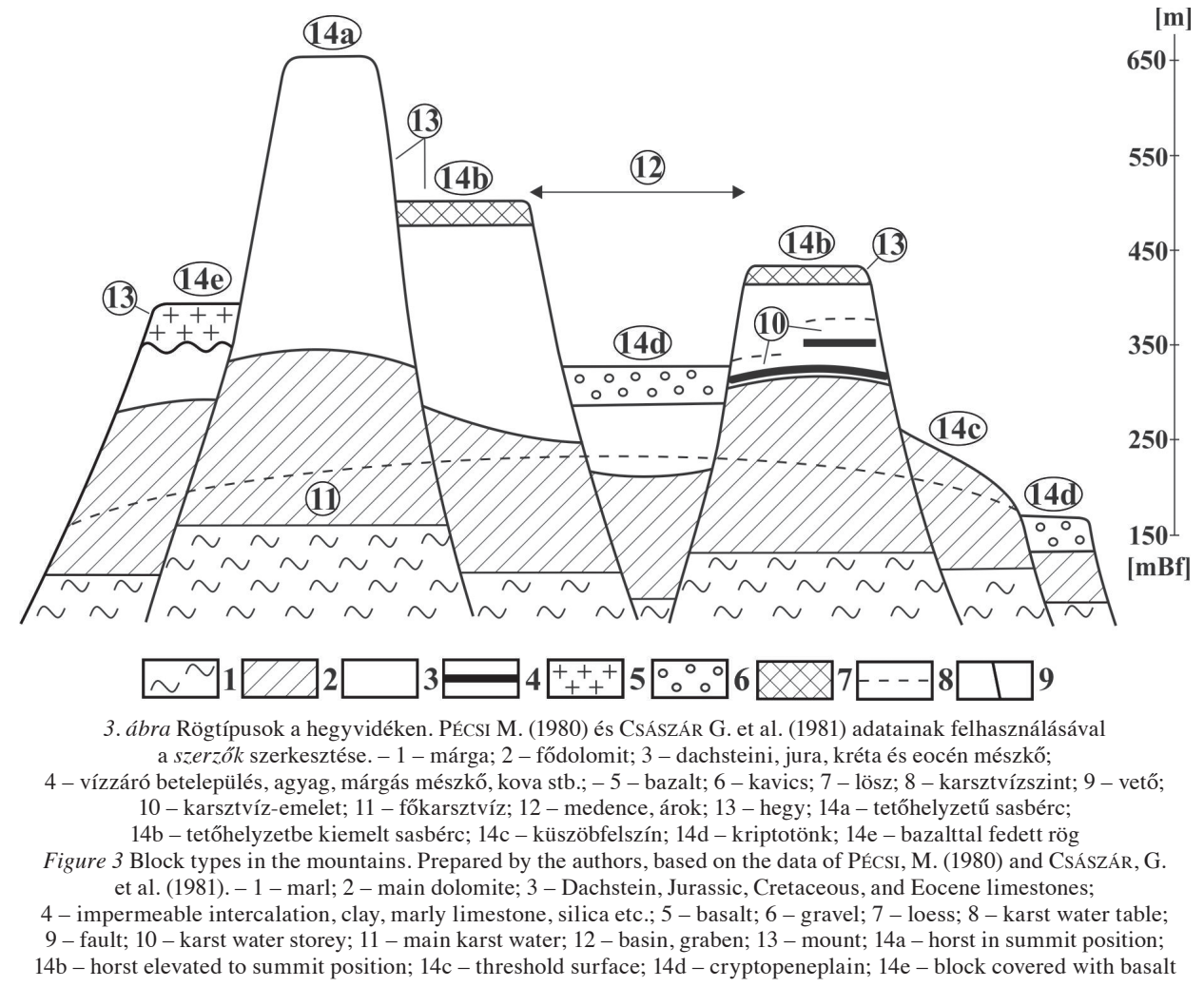

A hegység medencéi - a Hárskúti-medence és a Lókúti-medence D-i részének kivételével, amelyek tetőhelyzetbe kiemelt sasbércek - kriptotönkök.

\section{Karszttípusok és formáik}

A karszt fedettségének figyelembevételével különböző karszttípusok különíthetők el (Gvozdetskiy, N. A. 1965; Hevesi A. 1986; JAKuCs L. 1971; Veress, M. 2016): csupasz, talajos, fedett allogén, vegyes autogén-allogén, elszigetelten eltemetett (burried) karszt. A fedett karszt lehet eltemetett (a fedő vízzáró) és rejtett (a fedő vízáteresztô). Csupasz vagy talajos karszton, a szakadék- és eltemetett karszton az átöröklődéses, rejtett karszton az utánsüllyedéses dolinák a jellegzetes karsztformák (SwEETING, M. M. 1973; Waltham, T. et al. 2005). Az allogén és a vegyes autogén-allogén karszt formái 
a ponorok (JAKUCS L. 1971; Ford D. C.-WiLliams, P. W. 2007). Elszigetelten eltemetett a karszt, ahol nincs karsztosodás. Az utánsüllyedéses dolinák változatai a lezökkenéses és a szuffóziós dolinák (WILliams, P.W. 2004). Az utánsüllyedéses dolinák a fedőben alakulnak ki, alattuk a fekün is lehet mélyedés és a feküben mindig van karsztos járat (akna). Az utánsüllyedéses dolinák lehetnek szingenetikusak és posztgenetikusak (VERESS, M. 2008, 2009, 2016). Az előbbiekben a fekü járatának (akna) és a fedón a depressziónak a képződése egyidejű, míg a posztgenetikus dolináknál a fekü járata (akna) a fedő depreszsziójának (vagy legalább egy része) kialakulásánál idősebb. Ezért a posztgenetikus dolinák alatt a fedőben lencsés üledékszerkezetek vannak (VERESS, M. 2008, 2016), amelyek az idősebb depresszió feltöltődése során alakultak ki.

A szakirodalmi adatok szerint az utánsüllyedéses dolinák száma, gyakorisága és a fedő vastagsága között kapcsolat van. Kínában a számba vett utánsüllyedéses dolinák 60\%-a 5 m-nél, 85\%-a 10 m-nél kisebb vastagságú fedőn alakult ki (YUAN, D. 1987; CHEN, J. 1988).

A rejtett karszt formája a fedőüledékes depresszió is. Ezek mélységükhöz képest nagy átmérőjú alakzatok, talpukon olyan formákkal (utánsüllyedéses dolina és/vagy víznyelő), amelyek a fedőt a karsztba továbbítják. A fedőüledékes depressziók a fekü morfológiája szerint lehetnek áldepressziók (a fekün nincs zárt mélyedés) és igazi depressziók (a fekün van zárt mélyedés; VERESS, M. 2009, 2012, 2016).

\section{Módszerek}

Vizsgálataink során többféle módszertani megközelítést alkalmaztunk.

1. A nem karsztos fedő minősítésével és a különböző karsztformák figyelembevételével a hegységben különböző karszttípusokat különítettünk el:

- rejtett karsztos térszínek, ahol a fedô vízáteresztő (elsôsorban lösz) és ott utánsülylyedéses dolinák vannak;

- eltemetett karszt, ahol a fedő konszolidált vízzáró kőzet és azon átöröklődéses dolinák vannak;

- elszigetelten eltemetett karszt, ahol a fedő vízzáró, nem konszolidált kőzet és a pereménél szurdokok vannak;

- vegyes autogén-allogén karszt, ahol a vízzáró elvégződésénél víznyelők fordulnak elő.

2. 1:10000-es méretarányú térképek felhasználásával karsztmorfológiai térképezést végeztünk és terepbejárások során kijelöltük a jelentősebb karsztjelenség-csoportok előfordulását. Nagy (1 :500-as) méretarányú karsztmorfológiai térképeket készítettünk a Tésifennsík, a Mester-Hajag és a Kab-hegy egy-egy részletéról.

3. Vizsgáltuk a Márvány-árok környékén a völgyközi hátak szélessége és az utánsülylyedéses dolinák gyakorisága közötti kapcsolatot.

4. Keresztszelvények mentén - a Terratest Kft. munkatársainak kivitelezésében - VESZméréseket (vertikális elektromos szondázást) végeztettünk a Tési-fennsíkon, a Hárskútimedence területén (Homód-árok), az Eleven-förtés töbörcsoport területén, a Mester-Hajagon, a Fehérkő-árok környékén összesen 43 utánsüllyedéses dolinában és környezetükben, az azokat hordozó 11 fedőüledékes depresszióban, továbbá Devecser és Nyirád között, a Kígyós-, a Torna-, a Padragi-patak által közrefogott terület (a továbbiakban Devecser környéke összefoglaló néven említjük) néhány depressziójában. A mérések során két földelt elektródán át áramot vezetnek a felszín alá, majd másik két elektróda között mérik a létrejövó árameloszlás által okozott potenciálkülönbséget. Az árameloszlás és így a mért potenciálkülönbség, illetve az ebből számított, ún. látszólagos fajlagos ellenállás függ az egyes rétegek anyagának fajlagos ellenállásától és a rétegek vastagságától. A mért poten- 
ciálkülönbség-értékekből az elektródák távolságának függ vényében görbék szerkeszthetők, amelyek segítségével, egy inverziós programot használva, ideális esetben a rétegsor ellenállása és vastagsági paraméterei meghatározhatók. Az egyes helyekre számított rétegsorokat összeillesztve a kialakított mérési vonalak mentén geoelektromos-földtani metszetek szerkeszthetők (VERESS M. 2005), amelyek a fekü morfológiájára, a fedő vastagságára, összetételére és szerkezetére vonatkozó adatokat szolgáltatnak. A fedöüledék szerkezetének figyelembevételével minősítettük az utánsüllyedéses dolinákat: posztgenetikus a dolina, ha alatta a fedőben lencsésen települt összlet vagy a fekün feltöltött mélyedés van, szingenetikus, ha ezek a sajátosságok hiányoznak.

\section{Eredmények}

1. Megállapítottuk, hogy a különböző típusú rögökön különböző karszttípusok fejlődtek ki. (Egyes rögökön azonban több karszttípus is jelen lehet.) A tetőhelyzetű sasbérceken és a küszöbfelszíneken főleg a talajos karszttípus fordul elő, de a tetőhelyzetbe kiemelt sasbércek felszínén is megfigyelhető. A kriptotönkök területén elszigetelten eltemetett karszt van. Ilyen típusú karszt jellemzi a Dudari-medencét, a Lókúti-medence É-i részét és a Porvaimedence kavicstakarós területeit. Eltemetett és allogén karszt van a bazalttakarós rögökön (főleg a Kab-hegyen). A rejtett karsztos térszínek előfordulását az 1. táblázat mutatja be.

1. táblázat - Table 1

Utánsüllyedéses dolinacsoportok előfordulása a hegységben

The occurrence of groups of subsidence dolines in the mountains

\begin{tabular}{|c|c|c|c|c|}
\hline Előfordulási hely & $\underset{(\mathrm{m})}{\text { Magasságuk }}$ & Számuk & $\begin{array}{l}\text { Morfológiai } \\
\text { környezetuik }\end{array}$ & $\begin{array}{c}\text { A hordozó rög } \\
\text { típusa }\end{array}$ \\
\hline Tési-fennsík & $400-500$ & 137 & $\begin{array}{l}\text { sík térszín, völgytalp, } \\
\text { fedőüledékes depresszió }\end{array}$ & $\begin{array}{l}\text { tetőhelyzetbe } \\
\text { kiemelt sasbérc }\end{array}$ \\
\hline $\begin{array}{l}\text { Márvány-árok környéke } \\
\text { (Kőris-h. É-i része) }\end{array}$ & $360-500$ & 120 & $\begin{array}{l}\text { völgyközi hátakon } \\
\text { völgyekben }\end{array}$ & $\begin{array}{l}\text { tetôhelyzetbe } \\
\text { kiemelt sasbérc }\end{array}$ \\
\hline Mester-Hajag & $440-500$ & 85 & $\begin{array}{l}\text { magaslatok közti térszí- } \\
\text { neken, illetve ezek fedő- } \\
\text { üledékes depresszióiban }\end{array}$ & $\begin{array}{l}\text { tetôhelyzetbe } \\
\text { kiemelt sasbérc }\end{array}$ \\
\hline $\begin{array}{l}\text { Som-hegy és Száraz- } \\
\text { Gerence között }\end{array}$ & $400-500$ & 76 & $\begin{array}{l}\text { sík térszínen, } \\
\text { völgytalpon }\end{array}$ & $\begin{array}{l}\text { tetôhelyzetbe } \\
\text { kiemelt sasbérc }\end{array}$ \\
\hline Hárskúti-medence & $420-500$ & 60 & $\begin{array}{l}\text { sík térszín, völgytalp, } \\
\text { völgyoldal }\end{array}$ & $\begin{array}{l}\text { tetôhelyzetbe } \\
\text { kiemelt sasbérc }\end{array}$ \\
\hline Égett-hegy & $440-470$ & 25 & $\begin{array}{l}\text { magaslatok közti térszí- } \\
\text { neken, illetve ezek fedő- } \\
\text { üledékes depresszióiban }\end{array}$ & $\begin{array}{l}\text { tetőhelyzetbe } \\
\text { kiemelt sasbérc }\end{array}$ \\
\hline Kab-hegy & $400-450$ & $20 *$ & $\begin{array}{l}\text { völgytalpon, átörökloo- } \\
\text { déses dolinában, víz- } \\
\text { nyelőben, sík térszínen }\end{array}$ & $\begin{array}{l}\text { bazaltsapkás } \\
\text { sasbérc }\end{array}$ \\
\hline $\begin{array}{l}\text { Iharos-tető és Judit-forrás } \\
\text { közötti terület (Kertes-kő) }\end{array}$ & $390-410$ & 21 & sík térszínen & $\begin{array}{l}\text { tetôhelyzetbe } \\
\text { kiemelt sasbérc }\end{array}$ \\
\hline Felső-Hajag & $440-500$ & $20 *$ & $\begin{array}{l}\text { magaslatok közti } \\
\text { térszínen }\end{array}$ & $\begin{array}{l}\text { tetôhelyzetbe } \\
\text { kiemelt sasbérc }\end{array}$ \\
\hline $\begin{array}{l}\text { Cuha és Gézaháza-puszta } \\
\text { között }\end{array}$ & $450-470$ & $14^{*}$ & $\begin{array}{l}\text { sík térszínen, fedő- } \\
\text { üledékes depresszióban }\end{array}$ & $\begin{array}{l}\text { tetőhelyzetbe } \\
\text { kiemelt sasbérc }\end{array}$ \\
\hline
\end{tabular}




\begin{tabular}{|c|c|c|c|c|}
\hline Előfordulási hely & $\begin{array}{c}\text { Magasságuk } \\
(\mathbf{m})\end{array}$ & Számuk & $\begin{array}{r}\text { Morfológiai } \\
\text { környezetük }\end{array}$ & $\begin{array}{c}\text { A hordozó rög } \\
\text { típusa }\end{array}$ \\
\hline $\begin{array}{l}\text { Szabadhegyi-fennsík } \\
\text { (Keszthelyi-hegység) }\end{array}$ & $400-420$ & 13 & sík térszínen & $\begin{array}{l}\text { tetőhelyzetû } \\
\text { sasbérc }\end{array}$ \\
\hline Devecser közelében & $160-230$ & $10 *$ & sík térszínen & küszöbfelszín \\
\hline Tapolca közelében & $120-180$ & $10^{*}$ & sík térszínen & küszöbfelszín \\
\hline $\begin{array}{l}\text { Kőris-hegy és Parajos- } \\
\text { tető között (Eleven Förtési } \\
\text { Dolinacsoport) }\end{array}$ & $670-680$ & 9 & $\begin{array}{l}\text { sík térszínen, } \\
\text { völgytalpon }\end{array}$ & $\begin{array}{l}\text { tetőhelyzetú } \\
\text { sasbérc }\end{array}$ \\
\hline $\begin{array}{l}\text { Dudar közelében (Dudari- } \\
\text { medence peremi része) }\end{array}$ & $350-400$ & 7 & sík térszínen & $\begin{array}{l}\text { kriptotönk } \\
\text { peremi része }\end{array}$ \\
\hline Középső-Hajag & $580-600$ & 6 & sík térszínen & $\begin{array}{l}\text { tetőhelyzetú } \\
\text { sasbérc }\end{array}$ \\
\hline $\begin{array}{l}\text { Tündér-major közelében } \\
\text { (Kő-hegy) }\end{array}$ & $350-400$ & 5 & sík térszínen & $\begin{array}{c}\text { tetőhelyzetbe } \\
\text { kiemelt sasbérc } \\
\text { vagy kriptotönk } \\
\text { pereme }\end{array}$ \\
\hline $\begin{array}{l}\text { Szépalma-puszta köze- } \\
\text { lében (Porvai-medence } \\
\text { peremi részén) }\end{array}$ & $400-450$ & 4 & völgytalpon & $\begin{array}{l}\text { tetőhelyzetbe } \\
\text { kiemelt sasbérc }\end{array}$ \\
\hline Fehérkő-árok pereménél & $340-360$ & 4 & $\begin{array}{l}\text { magaslatok közti fedő- } \\
\text { üledékes depresszióban }\end{array}$ & $\begin{array}{l}\text { tetôhelyzetbe } \\
\text { kiemelt sasbérc }\end{array}$ \\
\hline $\begin{array}{l}\text { Lókút közelében } \\
\text { (Lókúti-medence) }\end{array}$ & $400-450$ & 3 & völgytalpon (?) & $\begin{array}{l}\text { tetőhelyzetbe } \\
\text { kiemelt sasbérc }\end{array}$ \\
\hline Ősbükkösi dolinacsoport & $400-450$ & 3 & völgytalpon & $\begin{array}{l}\text { tetőhelyzetbe } \\
\text { kiemelt sasbérc }\end{array}$ \\
\hline Súrú-hegy & $400-440$ & 2 & sík térszínen & $\begin{array}{l}\text { tetóhelyzetbe } \\
\text { kiemelt sasbérc }\end{array}$ \\
\hline
\end{tabular}

* = becsült érték.

Kimutattuk, hogy az összes rejtett karsztos terület $68,18 \%$-a tetóhelyzetbe kiemelt sasbércen van. E területeken fordul elő az utánsüllyedéses dolinák többsége. A becsült dolinák darabszámát is figyelembe véve a 691-ből 616 van az ilyen típusú sasbérceken. Az alacsony küszöbfelszíneken mindössze 2, a tetőhelyzetú sasbérceken 3 rejtett karsztos terület van, továbbá 1-1 fordul elő kriptotönkön és bazalttakarós rögön. Valamely rögtípusba tartozó rögök aránya szerint az Északi-Bakonyban a tetőhelyzetbe kiemelt rögöknek 32\%-án van rejtett karszt, míg a tetôhelyzetú sasbérceknek a 9,1\%-án, a kriptotönköknek a 12,5\%-án.

2. A karsztmorfológiai térképezés eredményeként az alábbi megállapítások tehetôk:

- A hegység rejtett karsztos térszínein elkülöníthetők a nagy átmérőjű fedőüledékes depressziók, továbbá az azokban előforduló utánsüllyedéses dolinák (4., 5. és $6 a$. ábra).

- A középsőkréta mészkőből (Zirci Mészkő Formáció) felépült rögökön (Mester-Hajag, Égett-hegy) exhumálódott mészkőmagaslatok sorakoznak nagy sűrüségben (6a.ábra). E kis kiterjedésú rögöket völgyek fogják közre, ezért a fedő lepusztulása nagymértékú volt. Az elfedett mészkőmagaslatok részben exhumálódtak és jelenleg is exhumálódnak, amit a rögök billent helyzete jelentősen elősegít. Az exhumálódás és a billenés miatt a felszín dőlése a Mester-Hajagon $>9^{\circ}$, Égett-hegyen $>2^{\circ}$. Az exhumálódó és 

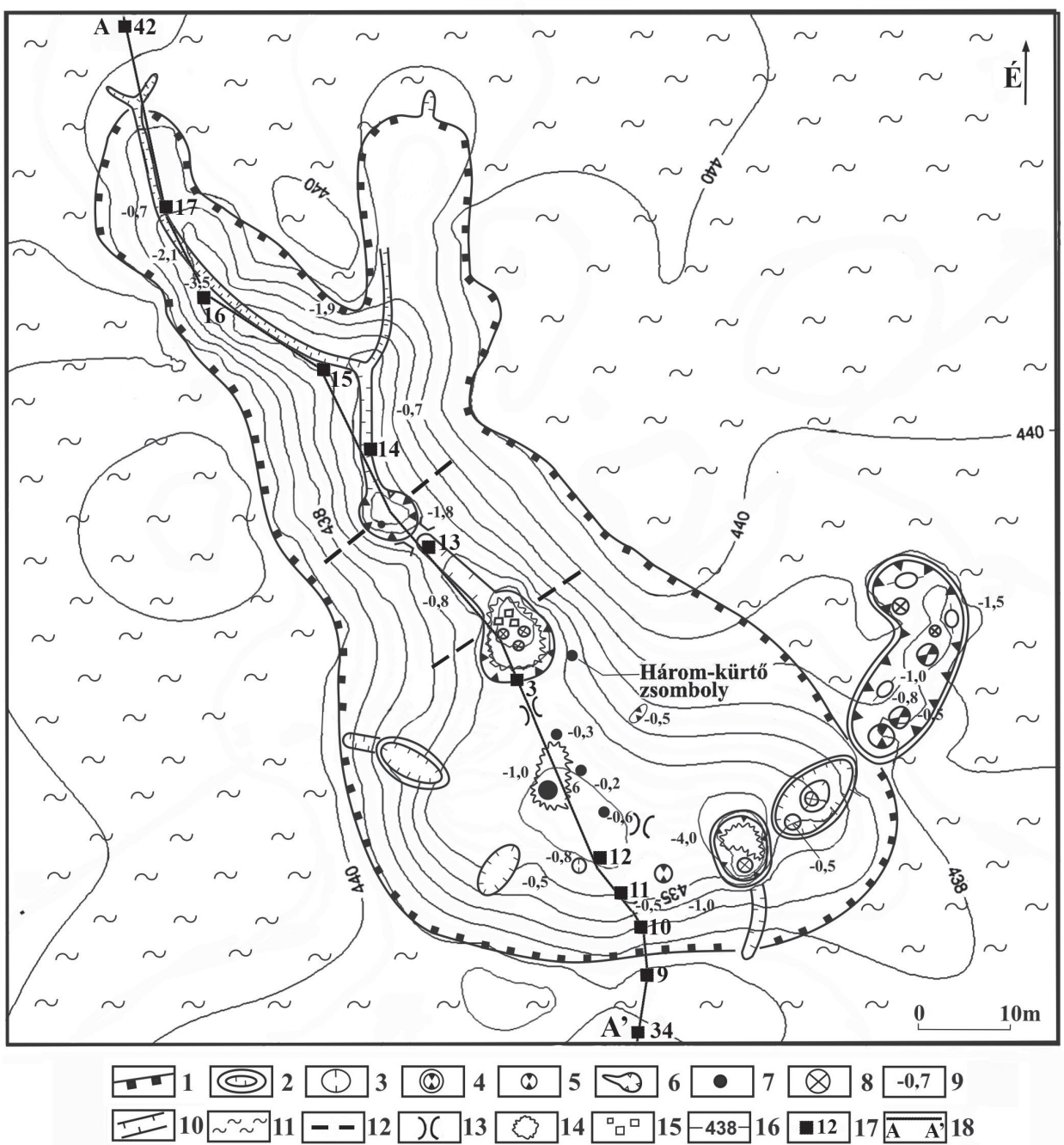

4. ábra A Háromkürtő-zsombolyt hordozó fedőüledékes depresszió (I-12 jelû) morfológiai térképe (VERESS M. 2016, módosított). - 1 - fedőüledékes depresszió pereme; 2 - szuffóziós dolina (átmérő: >2 m);

3 - szuffóziós dolina (átmérô: $<2 \mathrm{~m}$ ); 4 - lezökkenéses dolina (átmérō: $>2 \mathrm{~m}$ ); 5 - lezökkenéses dolina (átmérő: $<2 \mathrm{~m}$ ); 6 - víznyelő; 7 - kürtő, akna; 8 - járat a fedőben; 9 - forma mélysége; 10 - eróziós árok, meder;

11 - környező térszín; 12 - kőzethatár; 13 - nyereg; 14 - kőzetkibúvás; 15 - kőzettörmelék; 16 - szintvonal; 17 - VESZ mérési hely; 18 - VESZ-mérés szelvényének nyomvonala

Figure 4 The morphological map of the depression of superficial deposit (marked I-12) bearing Háromkürtő-shaft

(VERESS, M. 2016, modified). - 1 - margin of the depression of superficial deposit; 2 - suffosion doline

(diameter is larger than $2 \mathrm{~m}$ ); 3 - suffosion doline (diameter is smaller than $2 \mathrm{~m}$ ); 4 - dropout doline (diameter is larger than $2 \mathrm{~m}$ ); 5 - dropout doline (diameter smaller than $2 \mathrm{~m}$ ); 6 - ponor; 7 - chimney, shaft;

8 - passage in the cover; 9 - depth of the feature; 10 - gully, channel; 11 - surrounding terrain; 12 - rock boundary; 13 - col;

14 - outcrop; 15 - rock debris; 16 - contour line; 17 - site of VES measurement; 18 - line of VES measurement profile

exhumálódott magaslatokon nincs karsztosodás (csak akkor volt, amikor még fedővel borítottak voltak, aminek bizonyítékai az itt előforduló, lecsonkolódott aknák). A már exhumált magaslatok közötti térszínekről, ha a magaslatok sûrúsége nagy, a fedő maradéka már nem szállítódhat a határoló völgyekbe, aminek következtében 


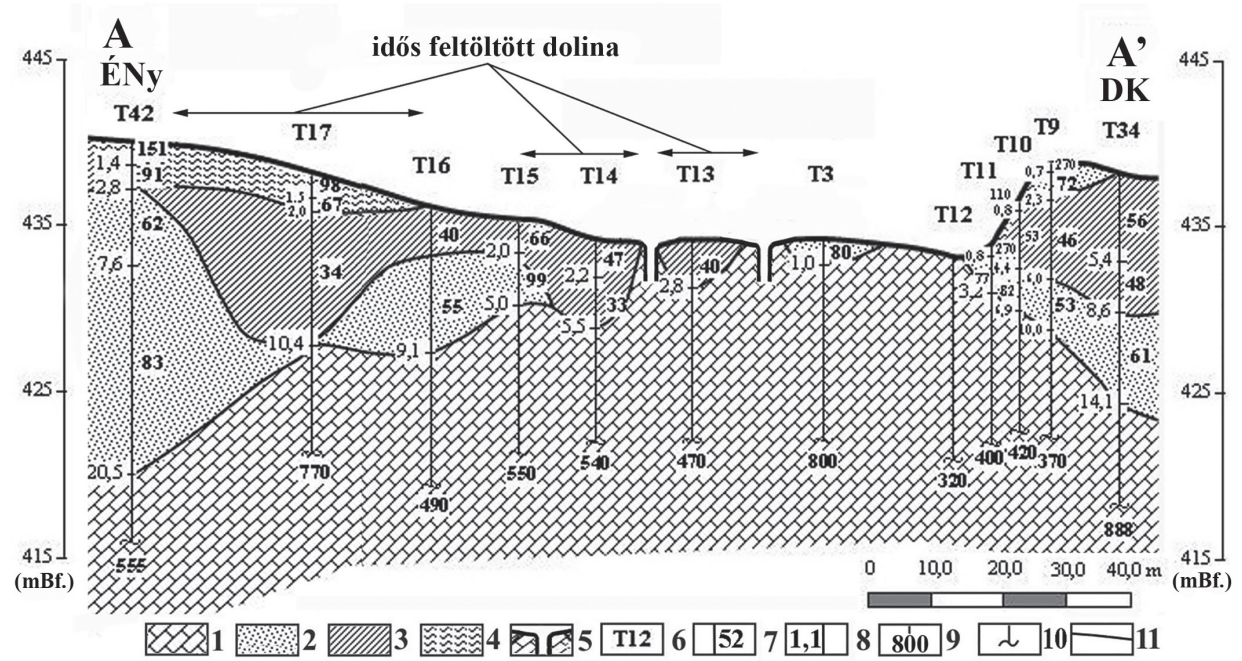

5. ábra A 4. ábrán bemutatott fedőüledékes depresszió geoelektromos-földtani szelvénye (VeRESS M. 2016, módosított). - 1 - mészkő; 2 - lösz (homokos vagy mészkőtörmelékes); 3 - lösz (agyagos vagy iszapos) vagy mészkőtörmelékes agyag; 4 - mészkőtörmelék (agyagos); 5 - kürtő; 6 - VESZ-mérés jele; 7 - összlet geoelektromos ellenállása (Ohmm); 8 - geoelektromos összlet talpmélysége $(\mathrm{m}) ; 9$ - fekü geoelektromos ellenállása $(\mathrm{Ohmm}) ; 10$ - VESZ-mérés körülbelüli behatolása; 11 - geoelektromos összlethatár

Figure 5 The geoelectric-geological profile of the depression of superficial deposit presented in Figure 4 (VERESS, M. 2016, modified). - 1 - limestone; 2 - (sandy) loess (with limestone debris);

3 - loess (clayey or silty) or clay with limestone debris; 4 - (clayey) limestone debris; 5 - chimney; 6 - code of VES measurement; 7 - geoelectric resistivity of series $(\mathrm{Ohmm})$;

8 - base depth of geoelectric series (m); 9 - geoelectric resistivity of bedrock $(\mathrm{Ohmm}) ; 10$ - approximate penetration depth of VES measurement; 11 - boundary of geoelectric series

fedő̈iledék-foltok maradnak meg. A magaslatok közötti, fedővel borított térszíneken karsztosodás folyik. A nagyobb területű rögökön (pl. Tési-fennsík) viszont a fedő lepusztulása, következésképp a fekü magaslatainak exhumálódása nem történik meg. A felszíni lepusztulás hiányát mutatja a lösz egységes elterjedése és például az, hogy a felszín dőlése a Háromkürtő-aknát hordozó (I-12 jelú) depresszió környékén $1^{\circ}$-nál kisebb. Emiatt rejtett karsztosodás történik a fekü vékonyan elfedett magaslata feletti sík felszínen (4., 5. ábra).

- Felismerhetők a bazalttakaróból (Kab-hegy) előbukkanó mészkőfoltok (magaslatok), amelyek lokális karsztosodási helyek. A karsztosodáshoz itt hozzájárulnak a mészkőfoltokat övező bazalttörmelék-sáncok. Ezek ugyanis növelik e mészkőfoltok körüli térszínek lefolyástalanságát (7. ábra).

3. A VESZ-mérések adataiból és a felhasználásukkal készített geoelektromos-földtani szelvényekből az alábbi eredményekre jutottunk:

- A vizsgált 43 utánsüllyedéses dolina közül 24 szingenetikus és 19 posztgenetikus. A fekü morfológiája szerint közülük 30 képződött elfedett, paleokarsztos magaslat felett (11 a fekü kitöltött, paleokarsztos depressziója felett, 2 sík, enyhén dőlő feküfelszín felett). Ami a szingenetikus dolinákat illeti, közülük 9 pereménél a fedővastagság 3,5 m-nél kisebb, 11 dolinánál 3,51-6,0 m közötti és 4-nél 6,01 m-nél nagyobb. Azért alakulnak ki egyre nagyobb eséllyel egyre vékonyabb fedőn, mert a beszivárgó víz egyre nagyobb eséllyel éri el a feküt és oda érkezve vékony fedőnél még oldóképes. A posztgenetikus utánsüllyedéses dolinák esetében a fedővastagság változatosabb: 2 dolinánál <3,5 m, 6-nál 3,51-6,0 m közötti és 11-nél nagyobb, mint 


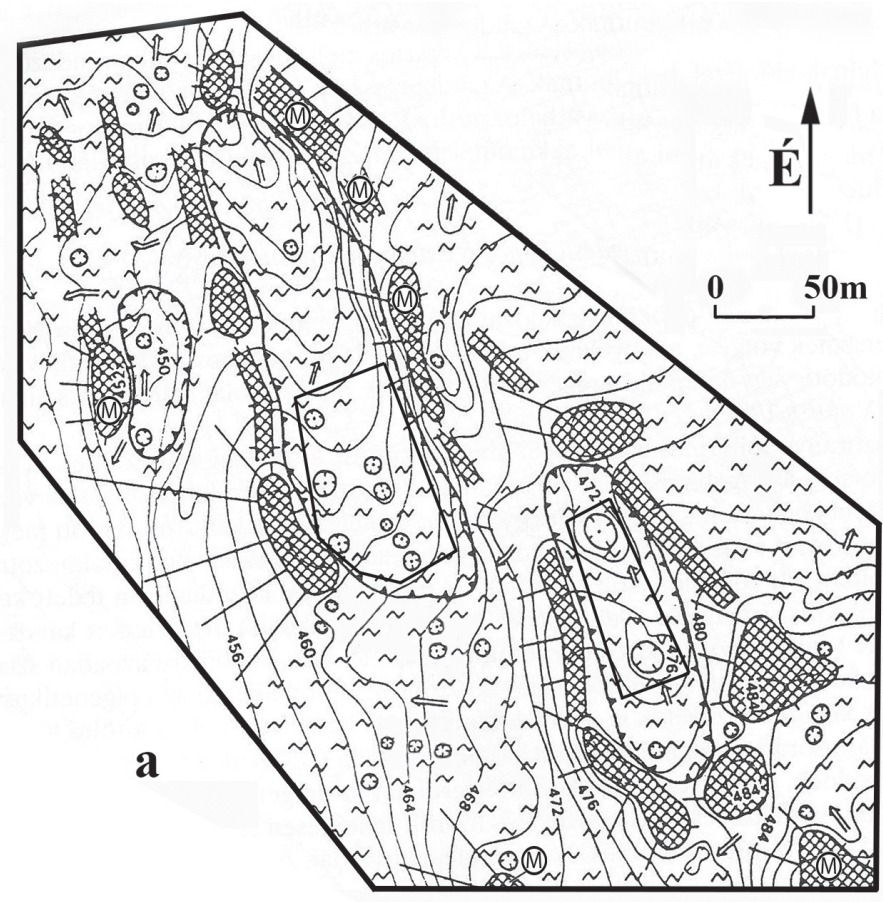

6. ábra Rejtett karszt:

a) exhumált mészkőmagaslatok között a Mester-Hajagról. b) völgyközi hátakról a Márvány-árok környékéről (a - VERESS M. 1999, módosított; b - a szerzők szerkesztése). - 1 - szintvonal; 2 - exhumált magaslat; 3 - félig exhumált forma (gerincszerú; de nem alkot magaslatot); 4 - mészkőelőbukkanás a magaslaton; 5 - exhumálódással kialakult magaslatok közötti karsztosodó fedőüledékes térszín; 6 - fedőüledékes depresszió; 7 - anyagáthalmozódás;

8 - szuffóziós dolina exhumált magaslatok közti térszínen; 9 - szuffóziós dolina völgyközi háton; 10 - szuffóziós dolina völgytalpon; 11 - vízelvezető járat karsztos mélyedésben; 12 - VESZ-mérések területe Figure 6 Concealed karst: a) between exhumed limestone mounds from Mester-Hajag. b) from interfluves from the environs of Márvány valley (a-VERESS, M. 1999, modified; $\mathrm{b}$ - prepared by the authors) - 1 - contour line; 2 - exhumed mound; 3 - semi-exhumed feature (it is ridge-like, but it does not constitute a mound); 4 - limestone outcrop; 5 - karstifying terrain with superficial deposit between mounds that developed by exhumation; 6 - depression of superficial deposit; 7 - material redeposition; 8 - suffosion doline between exhumed limestone mounds; 9 - suffosion doline on interfluves; 10 - suffosion doline on valley floor; 11 - water drainage passage in a karstic depression; 12 - area of VES measurements 
I.

a

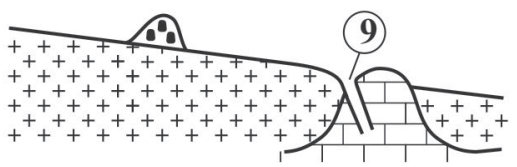

b
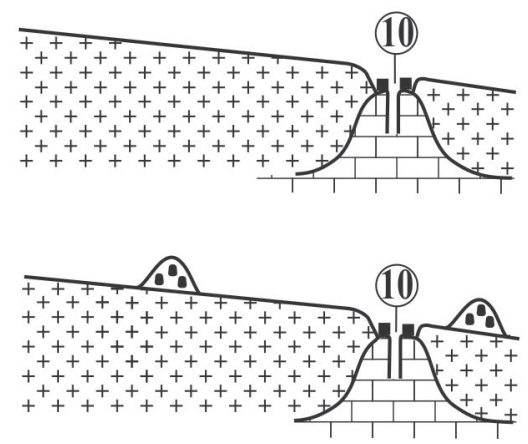

II.
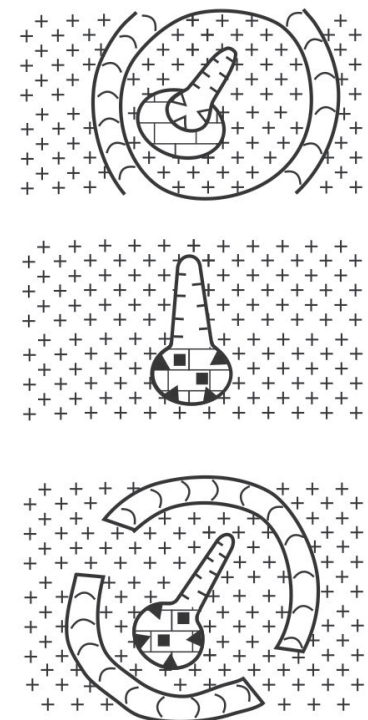

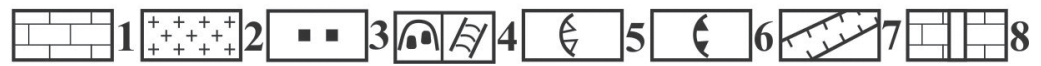

7. ábra Karsztos depressziók karsztos ablakoknál a Kab-hegyen (Veress M. 2016, módosított). - 1 - mészkő; 2 - bazalt; 3 - bazalttömb; 4 - bazaltsánc felül és oldalnézetben; 5 és 9 - víznyelő; 6 és 10 - átöröklődött dolina;

7 - völgy; 8 - akna, a - a - víznyelő és környezete oldal- és felülnézetben; b-c - átöröklődéses dolinák és környezetük oldal- és felülnézetben

Figure 7 Karst depressions at karst windows on Kab Mountain (Veress, M. 2016, modified). - 1 - limestone; 2 - basalt; 3 - basalt block; 4 - basalt barrier in plan view and in lateral view; 5 and 9 - ponor;

6 and 10 - caprock doline; 7 - valley; 8 - shaft, a -a - the ponor and its environs in lateral view and in plan view; $\mathrm{b}-\mathrm{c}-$ caprock dolines and their environs in lateral view and in plan view

6,01 m. Ennek az az oka, hogy nagyobb fedővastagságnál is létrejöhet posztgenetikus utánsüllyedéses dolina azért, mert a fedő anyaga a már meglevő aknán keresztül is képes a karsztba szállítódni anélkül, hogy a fekün oldódás történne (VERESS, M. 2009, 2016). A szakirodalmi adatokkal összhangban, összességében megállapítható, hogy a fedővastagság és a dolinaképződés gyakorisága között kapcsolat van. A szingenetikus utánsüllyedéses dolinák (de részben a posztgenetikusak is) egyre vékonyabb fedő esetén egyre nagyobb eséllyel jönnek létre.

- A hordozó felszín morfológiája szerint a vizsgált dolinák közül 18 sík felszínen, 15 völgytalpon (ezek egy része völgytalpi elfedett magaslat felett), 10 exhumált magaslatok közti térszíneken (pl. Mester-Hajag) van. Ez utóbbi térszíneken a fedő lepusztultsága hasonló, mint a völgytalpi helyzetű utánsüllyedéses dolináknál. Ugyanis az átlagos fedővastagság a szingenetikus dolináknál 3,85 m, a völgytalpi helyzetűeknél, a magaslatok közti térszínek dolináinál 3,95 m, míg a posztgenetikus dolináknál 6,18 m illetve 8,24 m. A fedő kivékonyodása miatt a Mester-Hajagon sík, enyhe dőlésû fekü felett is kialakulnak szingenetikus utánsüllyedéses dolinák (2 db). A fentiek figyelembevételével fedő-kivékonyodás vagy vékony fedő és így dolina-kialakulás a hegyvidéken négy morfológiai környezetben fordul elő: a fedőiuledékes átöröklődött völgytalpakon, vagy fedöüledékben mélyült völgyek talpán (1), az egyenetlen fekü 
elfedett magaslatai feletti sík felszíneken (2), az egyenetlen fekü exhumálódott magaslatai közötti térszíneken (3) és a nagy völgysűrúségű rögökön (4). A völgytalpakon a lineáris erózió vékonyította ki a fedôt. Magaslat felett a fedő egykori (felhalmozódás idejü) lokális vékonysága miatt és így annak lepusztulása nélkül is kialakulhat utánsüllyedéses dolina, például a már említett Háromkürtő-zsomboly depreszsziójánál (I-12 jelú; 4., 5. ábra). Magaslatokkal tagolt, feküs térszíneken a fedő lepusztulása olyan mértékú lehet, hogy - mint azt fentebb említettük - a magaslatok exhumálódnak és közöttük a fedő olyan mértékben kivékonyodik, hogy az ott megmaradt fedőfoltokon alakulnak ki az utánsüllyedéses (szuffóziós) dolinák (6a.ábra). Nagy völgysúrúségnél a völgyközi hátak keskenyek, így a fedő e helyeken ugyancsak kellő mértékben kivékonyodhat, miután az a határoló völgyekbe szállítódik. A Márvány-árok környékén (6b ábra) előforduló 120 utánsüllyedéses dolinából 74 völgyközi háton van. Ezek közül $48<200$ m szélességú (a völgyperemek távolsága szerint) és csak 18 db ahol a hát szélessége 200-300 m.

- A Devecser környéki depressziók alatt a fekün is mélyedés mutatható ki. Ez arra utal, hogy a fedő alatt a fekü depressziói oldódásos dolinák, amelyek áthalmozott fedővel utólag részben kitöltődtek (8.ábra).

\section{Karszttípusok és formáik kialakulása}

A hegységben egymás szomszédságában különböző karszttípusok váltakoznak, ugyanakkor viszonylag nagy kiterjedésú nem karsztos térszínek is vannak. Olyan területek tartoznak ide, ahol nem (vagy rosszul) oldódó kőzetek fordulnak elő. Például a Déli-Bakonyban jelentős kiterjedésben bukkan felszínre márga (Veszprémi Márga Formáció). Karsztjának változatosságához hozzájárulnak a patakmedrek mészkiválásai (főleg a Balaton-felvidéken) és a homokkőtömbökön kialakult karrok (a Káli-medence kőtengerei). Ezek bemutatására terjedelmi okokból nem térünk ki.

Egy-egy rögön, rögcsoporton gyakran csak egy-egy karszttípus terjedt el (többnyire talajos karszt vagy rejtett karszt). Gyakoribb azonban, amikor együtt fordul elő talajos, rejtett, illetve eltemetett karszt ugyanazon a rögön. Ezek kiterjedése és mintázata rögönként más és más lehet.

\section{Talajos karszt}

Talajos karszt bármely rögtípuson előfordulhat, de elsősorban a tetőhelyzetú sasbérceken és a küszöbfelszíneken jellemző. A talajos karszttípus formái a talaj alatti karrok és az oldódásos dolinák (az utóbbiak a küszöbfelszíneken és dolomiton).

A talaj alatti karrokat gyökérkarrok, hasadékkarrok képviselik (de előfordulnak kürtőkarrok, madáritatók és rácskarrok is). Megfigyeléseink szerint talaj alatti, részben kitakart (elsősorban hasadék-) karrok a Hódos-éri Likas-kő környékéről, valamint a Balatonfelvidékről (Dörgicse határában) említhetők.

A mészkő talajos karsztjának oldódásos dolinái fordulnak elő a Devecser (8.ábra) és a Tapolca környéki (MóGA J. et al. 2011) hegységperemi küszöbfelszíneken. A dolinák képződésének egyik szükséges feltétele a hordozó térszín kis dőlése. Kimutatták, hogy a töbrös felszínek legnagyobb arányban a Mecsekben, a 2-7º-os dőlésú felszíneken fordulnak elő (LiPPMANN L. et al. 2008), továbbá a Miroč-hegységben a $12^{\circ}$-nál kisebb dőlésú felszínek 85\%-a dolinás, míg az ennél nagyobb dőlésúeknek csak a 23\%-a (TELBISZ T. et al. 2007). Úgy ítéljük meg, hogy a Bakonyvidéken az oldódásos dolinaképződéshez 

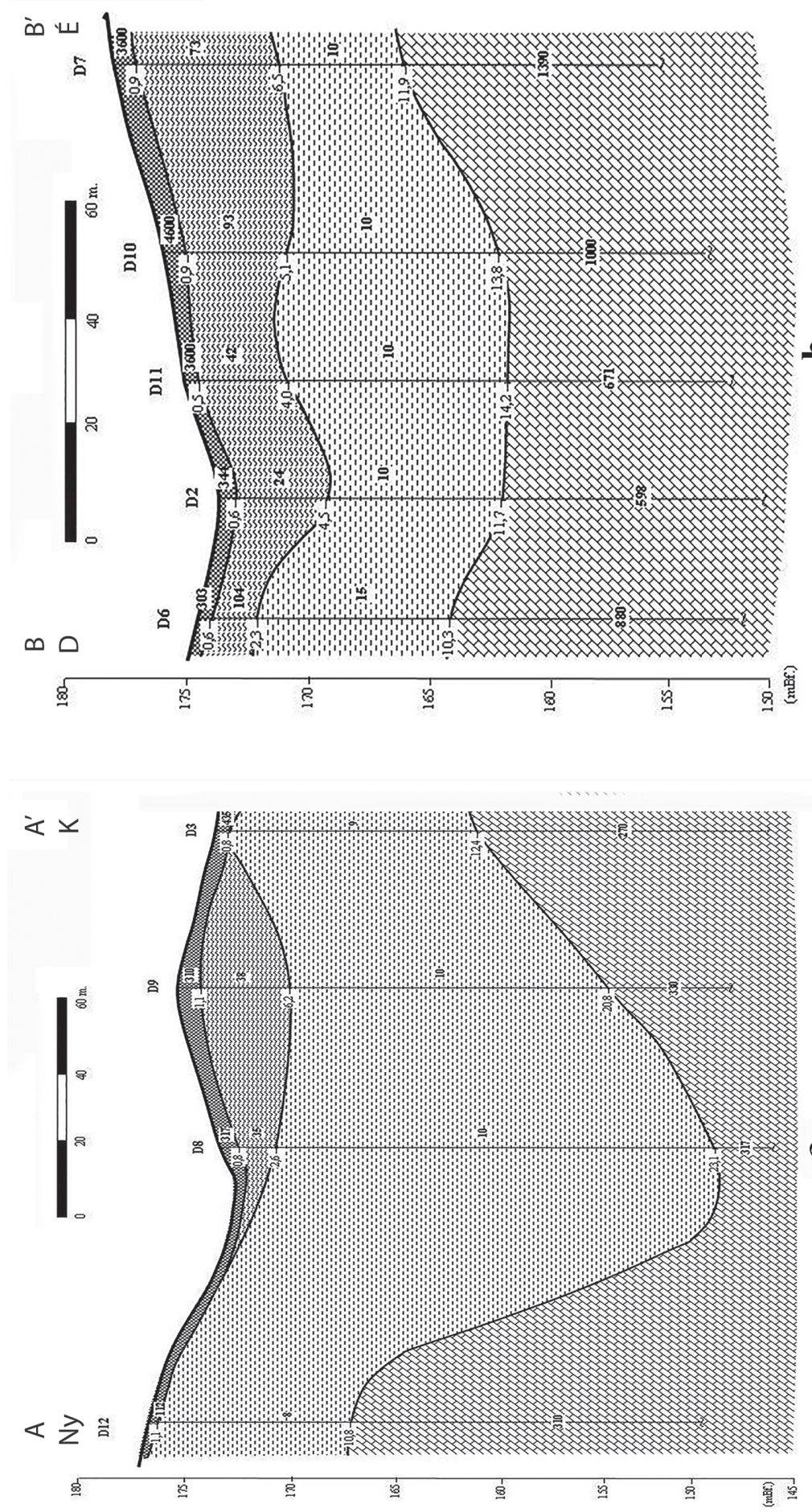
- a fenti területek kivételével - elsősorban a kis dőlésű felszínek hiányoznak. A Bakonyvidék magasabb rögein ugyanis a kis dőlésú talajos karszt kiterjedése kicsi. Például a Körishegy területén az Eleven-förtési dolinacsoport (ezek utánsüllyedéses dolinák) környékét leszámítva egyáltalán nincs $8^{\circ}$-nál kisebb dőlésú felszín.

Devecsernél több tucat, akár a 100 m-t is meghaladó átmérőjú, fedőüledékkel borított (részben feltöltött) depresszió fordul elő (némelyikben kicsi, fiatal, utánsüllyedéses dolinák is lehetnek) a középsőmiocén mészkövön (Lajta Mészkő Formáció). Ezek a vizsgált területen kivitelezett VESZ-mérések, illetve a kiszerkesztett geoelektromos-földtani szelvények szerint olyan oldódásos dolinák, amelyek különböző mértékben fel vannak töltődve. Az Egres-patak völgyétől Ny-ra, ahol a felszín magassága $<190$ m, a topográfiai térkép időszakos vízborítást jelöl a depressziókban (a völgytől K-re, ahol a felszín magassága >200 m, a vízborítás kevésbé vagy egyáltalán nem jellemző azokban), amit a csapadék hatására bekövetkező karsztvízszint-megemelkedéssel magyarázunk.

Tapolcánál, ahol a felszín magassága 120-180 m, a karsztos depressziók szarmata mészkőben (Tinnyei Formáció) képződtek. Itt változatosabb a formakincs: az oldásos dolinák mellett előfordulnak uvalák, szakadék- és utánsüllyedéses dolinák (MóGA J. et al. 2011), ső́t megfigyeléseink szerint, egy katavotra (Nyelőke) is előfordul. Az oldásos dolinák egy része kitöltés nélküli, de előfordulnak olyanok is, amelyekben lösz, homok és/vagy vörösagyag fedő van.

Talajjal fedett fődolomit-felszínek számos helyen fordulnak elő a hegységben. Közülük említésre méltó a Veszprém-Devecser közötti árok Márkótól K-re eső része, amely küszöbfelszín. Ennek karsztos jellemzői az alábbiak:

- Murvaösszlet fejlődött ki a szálban álló dolomiton, amelynek vastagsága K-i irányban Várpalotáig nő. Mivel JAKUCS L. (1971) szerint a dolomit aprózódása (porlódása) oldódás eredménye, a murvaösszletet a kőzet karsztosodása során kialakult képződménynek tartjuk (Veress M-SzABó L. 2000).

- Gyakoriak a nyitott, megnyúlt, sík aljzatú, völgyszerú formák, talpukon depressziókkal (VERESS M.-SZABó L. 2000).

- VerEss M-SzABó L. (2000) szerint kétféle zárt depresszió fordul elő, amelyek közös sajátossága, hogy mélységükhöz képest nagy átmérőjűek. Az egyik változat depressziói kisebb átmérőjúek (néhányszor 10 m-esek) és a magaslatok között, különböző szintekben fordulhatnak elő. A másik változat depressziói nagyobb átmérőjúek (több 100 m-esek) és magaslatokkal határoltak. Az e változatba tartozók között a legnagyobb már a Déli-Bakonyban található. Ez a magaslatokkal közrefogott Kövesgyưrpusztai depresszió (LÁNG S. 1958), amelynek az átméróje az 1 km-t is meghaladja, talpán a fekü egyenetlen és fedővel borított. Belsejéből vízmosással rendelkező víznyelőt (LÁNG S. 1958), illetve víznyelőket (JASKÓ S. 1961) említenek. A depressziók aljzatán kavics található, ami utólag halmozódhatott fel bennük. A kisméretú depreszsziók recens oldásos dolinák (VERESS M.-SzABÓ L. 2000), amelyek kavicsborításukat vesztett vagy kaviccsal el nem borított felszínen alakultak ki. A nagyobb átmérőjūek idősebbek és nem aktívak (bár belsejük karsztosodhat). Valószínú, hogy már környezetük kavicsborítása előtt kialakultak és azt követóen sem fedődtek el a Csatkai Kavics Formáció anyagával, hanem a földtani térkép adatai szerint (CsÁszÁR G. et al. 1981) utólag lösszel, folyóvízi homokkal és áthalmozott kaviccsal kibélelődtek.

- K-i irányban a felszínt egyre inkább magaslatok tagolják. A magaslatok mérete és sûrűsége a fenti irányban növekszik. A magaslatok magaslatcsoportokat is alkothatnak, amelyek lehetnek közös alapúak is. Az egyes magaslatok metszetben aszimmetrikusak, átellenes lejtőik hossza eltérő. (Magaslatokkal tagolt dolomittérszín említhető még Nyirád és Ódörögd környékéről is.) A magaslatok kialakulása és 
kialakulási kora nem ismert. Valószínú, hogy exhumált paleokarsztos formák (SzABó P. Z. 1968; MógA J. et al. 2011).

- A dolomit csupasz foltjain, főleg a völgyoldalakban (Séd-völgy, Tekeres-völgy) és a kisebb-nagyobb kőtömbökön (Kádárta) gyakoriak a karrok (SzABó L. 2000).

\section{Rejtett karszt}

A rejtett karsztos térszíneken a fedő főleg lösz, de ennek és a Csatkai Kavics Formáció, valamint az oldási maradék anyagának áthalmozott változatai is előfordulnak: lehet agyag, agyagos mészkőtörmelék, mészkőtörmelékes agyag, homokos vagy mészkőtörmelékes lösz, agyagos-iszapos lösz és lösz (VERESS M. 2006). E fedőüledékek kijelölik a rejtett karsztos térszínek előfordulását és elterjedését. A rejtett karsztos területek kiterjedése néhány $100 \mathrm{~m}^{2}$ és néhány $\mathrm{km}^{2}$ között változhat. Minthogy a tetőhelyzetú sasbércekról és a küszöbfelszínekről a fedő nagyrészt lepusztult, az e típusba tartozó rögökön e karszttípus hiányzik vagy korlátozottabban van jelen. Az utánsüllyedéses dolinák kialakulását a kriptotönkökön a vastag és vízzáró fedő gátolja. Ezért a rejtett karsztos felszínek fóleg a tetőhelyzetbe kiemelt sasbérceken fejlődtek ki, amelyeken a fentebb említett vízáteresztő fedőilledékek nagy kiterjedésben fordulnak elő ott, ahol a fedő vékony.

Mérésekkel kimutattuk, hogy a fedő kivékonyodhat vonalasan (völgytalpak), a középső-kréta térszínek kitakart mészkőmagaslatai között, vagy eleve vékonyan települt (a fekü magaslatai felett). (Ilyen tetőhelyzetbe kiemelt rög vagy rögrészlet a MesterHajag, az Égett-hegy, a Felső-Hajag, a Kertes-kő környéke és a Fehér-kő-árok környéke). Bár fedővastagság-adattal nem rendelkezünk, megfigyeléseink szerint a völgyközi hátak utánsüllyedéses dolináinál a keskeny völgyközi hátakon a fedő csekély vastagságú, amire a hátakon gyakori fekükőzet-előbukkanás és az utánsüllyedéses dolinák nagy száma utal.

Az utánsüllyedéses dolinák (a Tési-fennsíkiak kivételével) többnyire kis méretűek és változatos morfológiai környezetben fordulnak elő (1. táblázat). Völgytalpakon rejtett karszt van a Tési-fennsíkon, a Hárskúti-medence területén, a kitakart mészkőmagaslatok között a fentebb említett Mester-Hajagon, Égett-hegyen és Felső-Hajagon. Völgyközi háton, de völgytalpon is rejtett karszt van a Márvány-árok környékén. Megfigyeléseink szerint az utánsüllyedéses dolinák között többségben vannak a szuffóziós dolinák (1A kép), de előfordulnak lezökkenéses eredetúek is (1B kép). Morfológiájuk nagymértékben függ attól, hogy kapcsolódik-e hozzájuk eróziós árok, vízmosás, esetleg völgy. Előfordulnak közöttük vakvölgyes jellegúek is (fedett karsztos víznyelő). Az utánsüllyedéses dolinák kialakulásában a szuffózió (1A kép), a fedő (1B kép) és a fekü (1C kép) omlása külön-külön vagy együttesen is szerepet játszhatott.

Intenzív csapadékesemény után a dolinákban időszakos tavak alakulhatnak ki, amelyek élettartama igen eltérő lehet (VERESS M. 1987). A dolinák feltöltődéssel, illetve a mélyedés részük lepusztulásával hamar eltűnhetnek, ekkor csak az aknájuk marad meg (pl. a Kőris-hegyi Ördög-lik).

A fedőüledékes depressziók - mivel utánsüllyedéses dolináknál alakulnak ki - sík felszíneken, völgytalpakon és exhumált magaslatok közötti térszíneken fordulnak elő (4., 5. és $6 a$. ábra). Kialakulásuknak kedvez a korlátozott felszíni anyagszállítás. Ezt teszi lehetővé a felszín kicsi dőlése (sík felszínnél), az exhumált magaslat (a magaslatokkal tagolt fekünél), a sort alkotó utánsüllyedéses dolinák közül dőlésirányban az utolsó dolina (völgytalpnál).

A hegység fedőüledékes depressziói (4., 6a. ábra) uralkodóan áldepressziók (5. ábra). Igazi depresszió lehet az Eleven-förtési töbörcsoport területén, ahol megfigyeléseink szerint a töbörcsoportot mészkő-előbukkanások övezik, jelezve a fekü depressziós morfológiáját. 


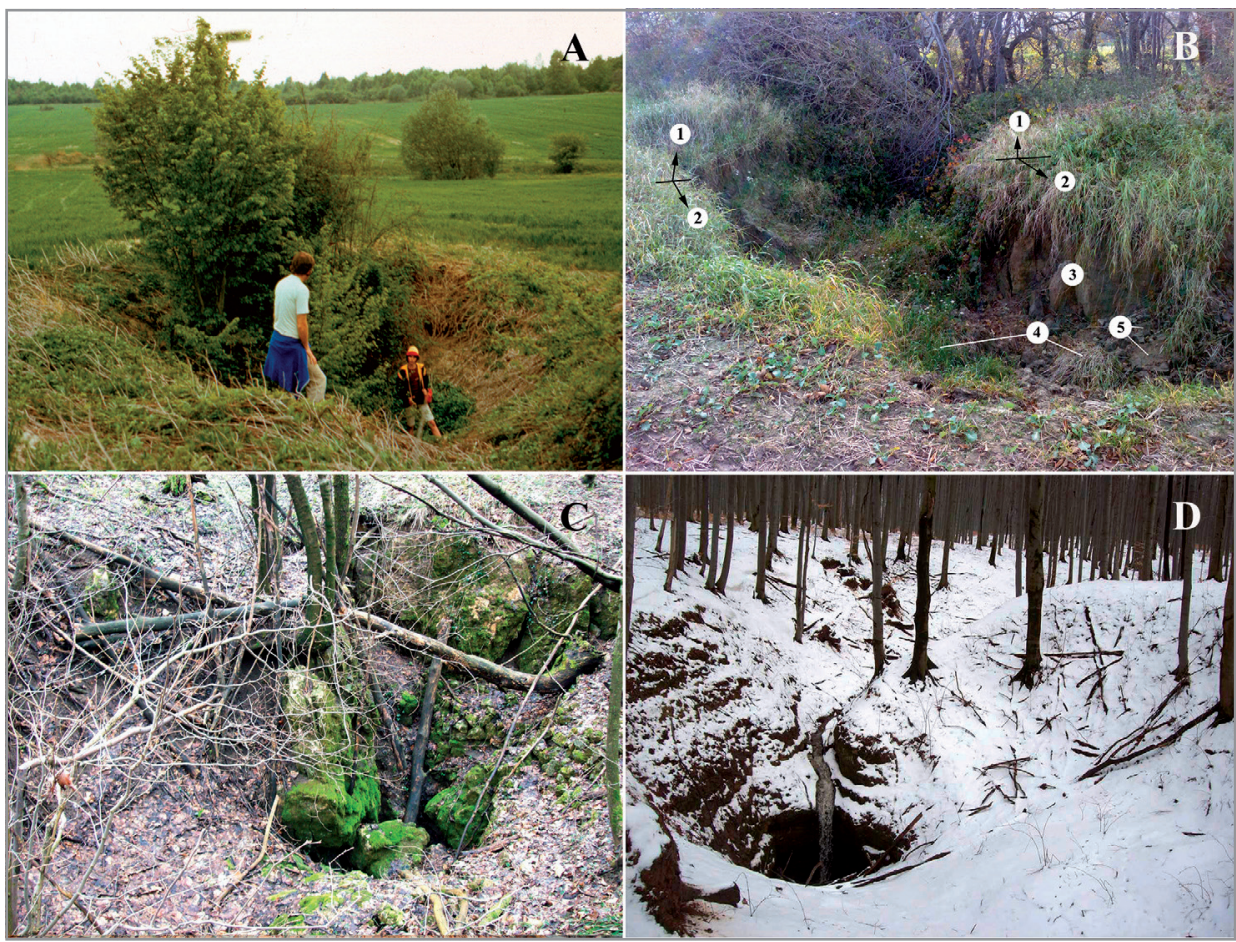

1. kép Karsztos depressziók: szuffóziós dolina (A), lezökkenéses dolina (B), a Csengő-zsomboly aknamennyezetének omlásával kialakult utánsüllyedéses dolina (C), Macska-lik víznyelő (D).

A - a Hárskúti-medence területéről; B és C - a Tési-fennsíkról; D - a Kab-hegyről. A szerző felvétele. - 1 - 2010 júliusa előtt kialakult mélyedésrész; 2 - 2010 júliusától kialakult töbörrész;

3 - a forma omlásos eredetű fala; 4 - omlással lezökkent növényzet; 5 - a fedő omlásos eredetű tömbjei

Picture 1 Karstic depressions: suffosion doline (A), dropout doline (B), which developed by the collapse of the ceiling of Csengő shaft, (C), Macska-lik ponor (D).

A - from Hárskúti basin; B and C - from Tési plateau; D - from Kab Mountain. Photo taken by the author.

- 1 - depression section formed before July 2010; 2 - doline section formed after July 2010; 3 - wall of the feature of collapse origin; 4 - vegetation displaced to lower position during collapse; 5 - collapse blocks of the cover

\section{Eltemetett karszt}

E karszttípus ott jön létre, ahol kavics (Csatkai Kavics Formáció), valamint bazalt (Tapolcai Bazalt Formáció) fedi a karbonátos térszínt.

\section{Kaviccsal fedett térszínek}

Az oligocén-miocén kaviccsal fedett térszínek területén (kriptotönk) nincs karsztosodás, viszont van folyóvízi felszínformálás (területük elszigetelten eltemetett karszt). A kavicsos térszínekről kilépő vízfolyások szurdokokat alakítottak ki, amelyek e térszínek tágabb értelemben vett karsztos megnyilvánulásainak tekinthetők.

Az elszigetelten eltemetett karsztos térszínek vízfolyásai átöröklődnek a karsztos feküre. Ennek során epigenetikus völgyeket hoznak létre, amelyeknek több változata is lehet az átöröklődés mértéke (átöröklődő epigenetikus völgy és átöröklődött epigenetikus völgy) és módja szerint (epigenetikus-regressziós völgy és epigenetikus-antecedens völgy). Az előzőek vízfolyásai hátrálás során mélyülnek a fekübe, tehát az átöröklődés a völgyfő irányába egyre fiatalabb. Az utóbbi völgyek egyes szakaszai már akkor átöröklődtek, ami- 
kor felsőbb részeik még nem, miután az antecedens szakaszok hordozó rögei (rögcsoport) emelkedtek (VERESS M. 1999). A kriptotönkök elszigetelten eltemetett karsztos térszíneinek peremén, a völgyek antecedens szakaszán vagy szakaszain szurdok vagy szurdokok alakultak ki. Szurdoka van például a Gerencének (Kertes-kői-szurdok), a Kő-árok patakjának (Kőmosó-szurdok), a Hódos-érnek, az Öreg-Sédnek (a Hárskúti-medence peremén a Kőszoros). Szurdokai vannak továbbá a Cuhának, az Ördög-árok patakjának és a Gajának is. E völgyszakaszok felett kialakulásuk idején, elszigetelten eltemetett karsztos térszínek voltak, s jelenleg is vannak, mint például a Kertes-kői-szurdok felett a Lókúti- és a Hárskúti-medence, az Ördög-árok szurdokai felett a Dudari-medence. De Zirc környéke is elszigetelten eltemetett karszt a Cuha szurdokos völgyszakaszai felett.

Az átöröklődött völgyek, különösen az antecedens szakaszok a felszíni vizek karsztba vezetésének fó pályái a hegyvidéken. Az Északi-Bakony 7 szurdokában évente 8 millió m³ víz vezetődik a karsztba (SCHMIDT ELIGIUS R. et al. 1962). Az elszivárgó víz vagy közvetlenül a főkarsztvízbe jut, vagy ha ennek szintje felett vízzáró van, karsztvíz-emeletet (lebegő karsztvíz) hoz létre, ahol üregesedés megy végbe (VERESS M. 1999). A szurdokokat határoló, nem karsztos térszínekről érkező vízfolyások áradások idején hordalékukkal jelentős mértékű eróziót végeznek. Az erózió felnyitja a szurdokok karsztvíz-emeleteinek freatikus üregeit. A felnyílt barlangok mennyezetüket veszítve sziklafolyosókká alakulnak (VERESS M. 1999). A szurdokok eróziós mélyülése, valamint a diffúz vízelvezetés nem kedvez depressziók és így víznyelők kialakulásának.

\section{Bazalttal fedett térszínek}

A Déli-Bakonyban és a Balaton-felvidéken a pliocénben (felsőpannon) bazaltvulkanizmus játszódott le (LócZY L. 1913; JUGOVICS L. 1954). Ennek során egyes rögök (Kab-hegy, Agártető, Fekete-hegy) karbonátos felszínei részben bazalttal fedődtek el (GYőRFFY D. 1957; LÁNG S. 1958). A bazalt paleokarsztos, magaslatokkal, depressziókkal és völgyekkel tagolt térszíneket borított el (LÁNG S. 1958). A kitörések szünetében vörösagyag (JÁMBOR Á. 1980), majd a pleisztocénben lösz keletkezett.

A bazaltos térszínek között (de a Bakonyvidék egészét tekintve is) a Kab-hegy karsztosodása a legfejlettebb (a karsztformák mérete és sűrúsége viszonylag nagy) és a legsokrétűbb. Előfordul itt vegyes autogén-allogén karszt, eltemetett és rejtett karszt is. Átöröklődéses dolinák előfordulnak például a Fekete-hegyen is.

Vegyes autogén-allogén karsztosodás történik a bazalttakaró pereménél (1D kép), a karsztos ablakoknál (7.ábra), allogén a bazalt átöröklődött völgyeinél (VERESS, M.-UNGER, Z. 2015; Veress, M. 2016). A karsztos ablakok a fekü magaslatai (NÉMETH R. 2005; MóGA, J.-NÉMETH, R. 2005). A karsztos eredetű magaslatokat vagy egyáltalán nem fedte el a bazalt, vagy csak kisebb vastagságban, mint a feküt máshol (VERESS, M. 2016). A bazalttakaró pereménél és azoknál a bazalttakaró belseji magaslatoknál, amelyeket nem fedett el a bazalt vakvölgyes víznyelők alakultak ki, mint például a Macska-lik (1D kép).

Völgy-átöröklődésnél feltárulhat a völgytalpon a mészkő (allogén karszt), ahol völgytalpi víznyelő alakul ki (Tönkölyös-víznyelő, a bazalttakaró egyik, Úrkúthoz közeli völgyében). Ha a völgy teljes hosszában átöröklődik, összetett, lefolyástalan karsztforma-rendszer jön létre (ilyen pl. az M-2 jelű karsztos rendszer). Ennek talpát aktív és nem aktív víznyelők, szuffóziós dolinák, peremét átöröklődéses, valamint lezökkenéses dolinák tagolják (Veress, M.-Unger, Z. 2015).

A bazalttakaró belsejében, ahol a mészkőmagaslat felett a bazalt vékony, eltemetett karszt alakul ki. E helyeken a feküben keletkezett kürtók felett a bazalt beomladozik. Ennek során átöröklődéses dolinák alakulnak ki (VERESS, M. 2016). E dolinákhoz hátráló vízmosások kapcsolódnak, amelyek vakvölggyé fejlődnek és a dolina víznyelővé alakul. Ez 
főleg akkor következik be, ha a dolinát hordozó karsztos ablak környezete az ablak körüli bazaltsáncok miatt lefolyástalan (7.ábra). Rejtett karsztos foltok alakultak ki a bazalttakaró karsztforma-rendszereiben, valamint a bazalttakarón kívüli, átöröklődött völgyek talpain.

Elsősorban a Kab-hegyen fordulnak elő sekély, gyakran több 100 m átmérőjű depreszsziók (de ilyen formák említhetők az Apáti-hegyről, a Tátika-csoport hegyeiről, a Kovácsihegyről is), állandó vizű vagy időszakos tavakkal. LEÉL-Ő́sSY S. (1959) szerint e formák paleokarsztos mélyedéseknél jöttek létre, ha azokat a bazaltláva csak részlegesen töltötte ki.

\section{A karsztosodás kora}

A Dunántúli-középhegység, de főleg a Bakonyvidék löszei 30 ezer évnél fiatalabbak (PÉCSI M. 1982). Ezért a nem áthalmozott löszben képződött szingenetikus utánsüllyedéses dolinák és a rejtett karsztosodás is e kornál fiatalabb. Ahol posztgenetikus dolinák is vannak, a rejtett karsztosodás kezdete is korábbi lehet, idősebb fedő egykori megléte esetén. Annak lepusztulását követően és a lösz kialakulása után kialakulhattak a posztgenetikus dolinák. A fedő lepusztulása, majd ismételt kialakulása miatt a rejtett karsztosodás egyes rögökön megismétlődhetett. A bazaltsapkás sasbérceken (Kab-hegy) a karsztosodás 2,7 millió évnél később kezdődhetett.

A rejtett karsztosodás relatív kora a különböző rögökön az alábbiak szerint alakulhatott:

- az átöröklődött völgytalpon a karsztosodás a völgytalpat kibélelő üledék keletkezésénél fiatalabb;

- az exhumált magaslatok közötti térszínek karsztosodása a rögperemi völgyek kialakulása után kezdődhetett;

- az oldódásos dolinák talpán a karsztosodás a fedőüledék kialakulása után mehetett végbe.

Miután a völgy-átöröklődés és a fedő áthalmozódása rögönként eltérő lehet a rögök eltérő idejü, mértékú és sebességú emelkedése miatt, a felszíni karsztosodás kezdete is eltéró az egyes rögökön.

\section{Összefoglalás}

A Bakonyvidék karsztja változatos, de a karsztos térszínek kis kiterjedésúek, távol esnek egymástól és a karsztformák is kisméretúek. Karsztosodása szigetszerú és uralkodóan kezdeti fázisban van, de az egyes rögök karsztosodásának kezdete a fedő eltérő mértékú és idejű kivékonyodása, továbbá a fekü eltérő mértékű és ütemú kitakaródása miatt különböző. Rögeinek (rögcsoportjainak) karsztosodása gyakran egyedi és különbözik a határoló rögök karsztosodásától. Recens felszíni karsztosodását meghatározta a rögös szerkezet, a rögök oszcillációja, a paleokarszt, a dolomit elterjedtsége, a fedőüledékek jelenléte és azok jelenleg is folyó lepusztulása. A rögös szerkezet és a vízzáró fedőüledékek jelenléte szurdokok kialakulásához és a freatikus barlangok felnyílásához járult hozzá. Az elfedett fekü magaslatai utánsüllyedéses dolinák, fedőüledékes depressziók és átöröklődéses dolinák kialakulását tették lehetővé.

A hegységben elterjedt, a talajos karszt, de az e típushoz köthető karsztformák fóleg a hegységperemi területeken (küszöbfelszínek) fordulnak elő. E rögtípus kis dőlésú felszínei kedveztek az oldódásos dolinák képződésének. A magasabb rögökön, ahol a kis dőlésú térszínek kis kiterjedésúek, ennek feltételei nincsenek meg. A hegység legjellegzetesebb karsztformáit mutató rejtett karszt elsősorban a tetőhelyzetbe kiemelt sasbérceken terjedt 
el, ahol a vízáteresztő üledékek viszonylag nagy kiterjedésben fordulnak elő. Formái elsősorban a fedő lokális kivékonyodásainál alakulnak ki: a völgytalpakon, az egyenetlen fekü elfedett magaslatai feletti sík térszíneken, az exhumált magaslatok közötti térszíneken és a keskeny völgyközi hátakon.

Eltemetett karsztos térszínen, ha a fedő bazalt, karsztosodás történik, mind a bazalt pereménél, mind a bazalt belsejében. Az utóbbi esetben a karsztosodás a fekü magaslatainál megy végbe (vegyes autogén-allogén karszt vagy eltemetett karszt), illetve ahol az átöröklődéses völgy átvágja a bazaltot (allogén karszt). Ha a karszt fedője kavics, annak elvégződésénél szurdokok jönnek létre felnyílásos barlangokkal.

A Bakonyvidék karsztján víznyelők csak a Kab-hegyen, oldódásos dolinák néhány peremi területen és dolomitfelszínen jöttek létre. Az oldódásos dolinák hiánya a fedő fiatal lepusztulására, a rögök kis kiterjedésére (a kis dőlésű felszín is kis kiterjedésû) vezethető vissza. A víznyelők hiánya az átöröklődött völgyek intenzív mélyülésével és diffúz vízelvezetésével magyarázható.

\author{
VERESS MÁRTON \\ ELTE SEK Földrajz Tanszék, Szombathely \\ veress.marton@sek.elte.hu \\ VETÉSI-FOITH SZILÁRD \\ PTE TTK Földtudományok Doktori Iskola, Pécs \\ szilard.vetesi@gmail.com
}

\title{
IRODALOM
}

BALOGH, K.-ÁRVA-Sós, E.-PÉCSKAY, Z.-RAVASZ-BARANYAI, I. 1987: K/Ar dating of post-Sarmation alkali basaltic rocks in Hungary. - Acta Mineral Petrogr., Szeged. 28 p.

Bulla B. 1968: A magyar föld domborzata fejlődésének ritmusai, az újharmadkor óta a korszerű geomorfológiai szemlélet megvilágításában. - Válogatott természeti földrajzi tanulmányok, Akadémia Kiadó, Budapest. pp. 90-104.

CsÁszÁr G.-CSEReKlei E.-Gyalog L. 1981: A Bakony-hegység földtani térképe (szerk.). - Magyar Állami Földtani Intézet, Budapest.

Chen, J. 1988: Karst collapses in cities and mining areas, China. - Environmental Geology Water Science, 12. pp. 29-35.

Csontos, L.- VöRÖs, A. 2004: Mesozoic plate tectonic reconstruction of the Carpathian region. - Paleogeography, Palaeoclimatology, Palaeoecology. 210. pp. 1-56.

Ford, D. C. - Williams, P. W. 2007: Karst Hydrogeology and Geomorphology. - John Wiley \& Sons, Chichester $561 \mathrm{p}$.

Gvozdetskiy, N. A. 1965: Types of Karst in the U.S.S.R. - Separatum, Prob. Speleol. Res. (Prague). pp. $47-54$.

GYőRFFY D. 1957: Geomorfológiai tanulmányok a Káli-medencében. - Földrajzi Értesítő 6. 1. pp. $265-299$.

Hevesi A. 1986: Hideg vizek létrehozta karsztok osztályozása. - Földrajzi Értesítő. 35. 3-4. pp. $231-254$.

JAKUCS L. 1971: A karsztok morfogenetikája. A karsztfejlődés varienciái. - Akadémiai Kiadó, Budapest. 310 p.

JASKÓ S. 1961: A balatonfelvidéki és észak-bakonyi patakok vízhozamának kapcsolata a földtani felépítéssel. - Hidrológiai Közlöny 41. 1. pp. 75-84.

JÁMBor Á. 1980: A Dunántúli-középhegység. - Magyar Állami Földtani Intézet Évkönyve LXII. Budapest. $244 \mathrm{p}$.

Jugovics L. 1954: A Déli-Bakony és a Balaton-felvidék bazaltterületei. - Földtani Intézet Évi Jelentése 1953ról. Budapest. pp. 65-88.

KoRPÁs L. 1981: A Dunántúli-középhegység oligocén-alsó-miocén képződményei. - Magyar Állami Földtani Intézet Évkönyve LXIV. Budapest. 140 p.

LÁNG S. 1958: A Bakony geomorfológiai képe. - Földrajzi Közlemények 82. pp. 324-346.

LEÉL-ÔSSY S. 1959: Adatok a dunántúli bazaltfelszíneken kialakult lefolyástalan mélyedések (kőtálak) eredetéhez. - Földrajzi Értesítő 2. pp. 271-273. 
LipPMAnN L.-Kiss K.-MóGA J. 2008: Az Abaliget-Orfúi-karszt karsztos felszínformáinak vizsgálata térinformatikai módszerekkel. - Karsztfejlődés XIII. pp. 151-166.

Lóczy L. 1913: A Balaton környékének geológiai képződményei és ezeknek vidékek szerinti telepedése. - A Balaton tudományos tanulmányozásának eredményei, I.. Budapest. 617 p.

MóGA, J.-NÉmETH, R. 2005: The morphological research of the basalt and loess covered plateaus in the Bakony Mts. (Transdanubian middle mts.-Hungary). - Acta carst(?)ologica 34.2 pp. 397-414

MóGA J.-Kiss K.-Szabó M.-KéRIné Borsodi A.-Kéri A.-MARi L.-KNÁB M.-IVÁN V. 2011: Természeti és antropogén hatások vizsgálata a Tapolcai-karszt epikarsztos rendszerében. - Karsztfejlődés XVI.pp. 185-201.

NÉMETH R. 2005: A Kab-hegyi bazalttakaró depresszióinak vizsgálata. - Karszt és Barlang 2000-2001 évf. pp. 33-41.

PÉCSI M. 1980: A Pannóniái-medence morfogenetikája. - Földrajzi Értesítő 29. 1. pp. 105-127.

PÉCSI, M. 1982: Quaternary studies in Hungary. - Elmélet - Módszer - Gyakorlat. Akadémia Kiadó, Budapest. $313 \mathrm{p}$.

PÉCSI M. 1991: Geomorfológia és domborzatminősítés. - MTA Földrajztudományi Kutató Intézet, Budapest. $296 \mathrm{p}$.

SChMidT Eligius R.-LÁNG S.-OzoRAy Gy. 1962: Adatok egyes középhegységeink vízháztartásához. - Vázlatok és tanulmányok Magyarország vízföldtani atlaszához. Műszaki Könyvkiadó, Budapest. pp. 48-56.

Stegena, L.-Geczy, B.-HorvÁth, F. 1975: Late Cenozoic evolution of the Pannonian Basin. - Tectonophysics 26. pp. 71-90.

Sweeting, M. M. 1973: Karst Landforms. - Columbia University Press, New York. 362 p.

SzABó L. 2000: Karros formák vizsgálata a Veszprémi-fennsík dolomitterületein. - Földrajzi Értesítő XLIX 1-2. pp. 27-41.

SzABó P. Z. 1956: Magyarországi karsztformák klímatörténeti vonatkozásai. - Földrajzi Közlemények 80. pp. $183-190$.

SzABó P. Z. 1968: A magyarországi karsztosodás fejlődéstörténeti vázlata. - Dunántúli Tud. Gyújtemény, Budapest. Series Geographica 34. pp. 13-25.

Telbisz T.-MARi L.-KoHÁN B.-JELEnA C. 2007: A szerbiai Miroč-hegység töbreinek térinformatikai GPS-es terepi vizsgálata. - Karsztfejlődés XII. pp.71-90.

VERESS M. 1987: Karsztos mélyedések múködése bakonyi fedett karsztokon. - Földrajzi Értesítő 36. 1-2. pp. 91-114.

VEREss M. 1999: Az Északi-Bakony fedett karsztja.-A Bakony Természettudományi Kutatásának Eredményei 23. Bakonyi Természettudományi Múzeum, Zirc. 167 p.

Veress M. 2005: Adalékok a Tábla-völgyi-dűlő (Tési-fennsík) fedett karsztosodásához. - Karsztfejlődés X. pp. 267-291.

VERESS M. 2006: Adatok a Tési-fennsík két térszínrészletének fedett karsztosodásához. - Karsztfejlődés XI. pp. 171-184.

VERESS M. 2008: A mészkőfekü morfológiájának hatása a fedett karsztosodásra az Északi-Bakonyban. - Karszt és Barlang 2004-2005. évf. pp. 33-54.

VERESS, M. 2009: Investigation of covered karst form development using geophysical measurements. - Zeits. f. Geomorph. 53. 4. pp. 469-486.

VERESS M. 2012: Fedőïledékes depressziók és kialakulásuk. - Földrajzi Közlemények 136. 1. pp. 2-21.

VerEss, M. 2016: Covered karsts. - Springer DOI10.1007/978-94-017-7518-2, 536 p.

VERESS M.-SzABó L. 2000: Adalékok a dolomit térszínek formáinak morfogenetikájához. - Földrajzi Értesítő XLIX. 1-2. pp. 13-26.

Veress, M.-Unger, Z. 2015: Kab mountain: Karst under a Basalt Cap. - In: LóCZY D. (ed.): Landscapes and Landforms of Hungary. Springer, Heidelberg/New York/Dordrecht/London. pp. 55-62.

Waltham, T.-Bell, F.-Culshaw, M. 2005: Sinkholes and Subsidence. - Springer, Berlin-Heidelberg. 382 p.

Williams, P. W. 2004: Dolines. - In: GunN J. (ed.), Encyclopedia of Caves and Karst Science, Fitzroy Dearborn, New York, London. pp. 304-310.

YUAN, D. 1987: Environmental and engineering problems of karst geology in China.- In: BECK B. F.-WILSON W. L. (eds.): Karst Hydrogeology: Engineering and Environmental Applications, Balkema: Rotterdam. pp. 1-11. 